\section{Firms' legitimation through corporate governance and its association with risk and return in Brazil}

Corporate governance and its association

Kléber Formiga Miranda

Universidade Federal Rural do Semi-Arido, Mossoro, Brazil

Jefferson Ricardo do Amaral Melo Universidade Federal do Delta do Parnaiba, Parnaíba, Brazil, and

Orleans Silva Martins

Universidade Federal da Paraiba, João Pessoa, Brazil

\section{5}

Received 1 May 2020 Revised 4 August 2020 16 September 2020 Accepted 17 October 2020

\begin{abstract}
Purpose - This study aims to examine the listing of firms at the highest corporate governance level of the Brazilian stock exchange (B3) as a means of legitimation and its relationship with risk and return on investment.

Design/methodology/approach - This paper analyzes 205 companies from 2010 to 2019, in which firms listed at the Novo Mercado level were compared with groups composed of other firms traded on B3.

Findings - The main results demonstrate that a listing at the supposedly higher level of corporate governance in Brazil does not indicate lower risk, a higher return or even a better risk-return ratio.

Research limitations/implications - The findings are restricted to this sample, representing the association identified between the analyzed phenomena and not a cause-effect relationship.

Practical implications - The highest level of corporate governance in Brazil brings together firms that present a higher risk (at least systematic) and lower returns (at least financial) because they seek to legitimize themselves in the market as firms committed to better management practices.

Social implications - These findings are useful to investors, the stock exchange, regulatory agents and the companies themselves to reflect on the purpose and usefulness of different levels of corporate governance in Brazil.

Originality/value - This study differs from the others that relate corporate governance to risk or return because it does not deal individually with corporate governance practices, but rather the phenomenon that is listed in a special governance level, created by the stock exchange, serving as a kind of seal legitimation.
\end{abstract}

Keywords Legitimacy, Risk, Corporate governance, Return

Paper type Research paper

(C) Kléber Formiga Miranda, Jefferson Ricardo do Amaral Melo and Orleans Silva Martins. Published in RAUSP Management Journal. Published by Emerald Publishing Limited. This article is published under the Creative Commons Attribution (CC BY 4.0) license. Anyone may reproduce, distribute, translate and create derivative works of this article (for both commercial and non-commercial purposes), subject to full attribution to the original publication and authors. The full terms of this license may be seen at http://creativecommons.org/licences/by/4.0/legalcode 
RAUSP

56,1

\section{Introduction}

This study analyzes the role of corporate governance as a means of legitimation and its relationship with risk and returns on investment in the Brazilian Stock Exchange $\left(\mathrm{B}^{3}\right)$. In this analysis, legitimation is understood as the adoption of voluntary practices to obtain the highest level of corporate governance, thus obtaining greater credibility in the face of the market; the risk is understood as the chance of failure of an investment; whereas the return is understood as the positive result of an investment.

The Brazilian market is considered in this analysis due to the unique opportunity to study the risk and return relationship considering different corporate governance classifications performed by the stock exchange. Based on practices that are additional to those required by national legislation, companies are classified into four levels in ascending order of requirements: Traditional level, Level 1, Level 2 and Novo Mercado.

In theory, the Novo Mercado has the highest level of corporate governance in the Brazilian capital market (Monte, Rezende, Teixeira, \& Besarria, 2010; Dalmácio, Lopes, Rezende, \& Sarlo Neto, 2013; Martins \& Paulo, 2014; Rossoni \& Mendes-Da-Silva, 2018). This is an important motivation for choosing this level as the highest standard of governance in Brazil, especially, as it is optional and has the largest number of practices to be adopted by companies. This seems to be a way for firms to legitimize themselves before the market because they start to be considered legitimate when they voluntarily opt for these differentiated and socially accepted practices, justifying the market expectation for better performance to other companies (Rossoni \& Machado-da-Silva, 2013).

This study does not address the analysis of corporate governance practices as risk factors, we take a look at the listing phenomenon at the highest level of corporate governance of $\mathrm{B}^{3}$ and its association with risk (Rossoni \& Mendes-Da-Silva, 2018) and return on investment (Fuenzalida, Mongrut, Arteaga, \& Erausquin, 2013). We address the fact that such listing has played an important role in legitimizing firms (Jonsson, 2020), particularly in information environments with low legal protection for investors, as usually occurs in emerging countries.

The economic environment of emerging countries is conducive to the adoption of corporate governance practices, only by external pressures (Şahin, 2015). In this context, Dalmácio et al. (2013) note that one of the main motivations for firms to adopt corporate governance practices in Brazil is their legitimacy with the market. Legitimacy can be defined as the need for a company to establish itself as legitimate in the face of the market (Woodward, Edwards, \& Birkin, 1996). The adoption of management practices well accepted by the market can be a strategy to legitimize the company, being part of a group that benefits the investment environment (Şahin, 2015).

Previous studies in the Brazilian market report divergent evidence that depends on the proxy used for risk and return. For example, Espejo and Clemente (2016) found greater sensitivity of the firms in the higher levels of corporate governance to the financial crisis of 2008, with higher volatility and fall in the stock prices (lower returns), in the opposite to firms at the lower levels of governance. This is different from Monte et al. (2010), who suggest that there is less volatility among listed companies at the Novo Mercado level when compared with companies at the other $\mathrm{B}^{3}$ listing levels.

From the viewpoint of return, Silveira and Barros (2008) note that investors better evaluate firms whose governance structures are appropriate to the Brazilian corporate governance code, being at higher levels of governance on the stock exchange, and thus having an implicit relationship to the stock returns. For them, being at a higher level of governance would be a rational strategy for adoption by firms, given their ability to legitimize themselves and provide higher returns to investors. On the other hand, 
Fernandes, Dias and Cunha (2010) did not find persistence in a similar relationship under the prism of the financial return.

In the related literature, it is common to identify studies analyzing the relationship between governance practices and variables such as risk (Monte et al., 2010; Milani, Righi, Ceretta, \& Dias, 2012; Lameira, 2012; Jonghe, Disli, \& Schoors, 2012) and return (Milani et al., 2012; Jonghe et al., 2012; Silva et al., 2012). In general, these studies point to a positive (negative) relationship between the adoption of corporate governance practices and return (risk). In contrast, in this study, we do something different because we do not analyze the practices themselves. We analyzed the phenomenon of being listed at a level classified by the stock exchange itself as "differentiated," serving as a sign of legitimacy regarding lower (higher) risk (return).

In this context, Rossoni and Mendes-Da-Silva (2018) analyzed the Brazilian market between the years 2002 and 2007, looking at whether the visibility is given by the listing at the "young Novo Mercado" moderated the effects of legitimacy (formal, regulatory, culturalcognitive and normative) on systematic risk. Considering this listing, the authors found a moderating effect of legitimation on systematic risk, under certain conditions. In the end, they suggest expanding this evidence to non-systematic risk, not addressed by them.

Thus, we highlight the relevance of this study by considering the research opportunity and the lack of a previous study that has presented evidence about the effects of such a phenomenon of legitimation on risk and return. We made significant progress on the evidence by Rossoni and Mendes-Da-Silva (2018), analyzing not only the effect on systematic risk but non-systematic risk, financial and economic returns, in addition to the risk-adjusted return. Unlike previous studies that approached this market, we contribute to a better understanding of the benefits of listing at these levels, as a process of legitimation.

In our findings, we perceive that the riskiest companies are more likely to be listed at the Novo Mercado level and not the most profitable ones. This issue is important for investors because, based on common sense, the Novo Mercado brings together firms with better governance practices, which would indicate to the market not only less risk but also greater credibility and efficient allocation of resources in the capital market. What we see is that the listing works as a sign of credibility (legitimation), but not as an indicator of lower risk.

The results of this study indicate the legitimacy of firms as an aspect to be considered in investment decisions in the Brazilian stock market. This is our main contribution because it is possible to conclude that the listing at the supposedly higher level of corporate governance does not indicate lower risk, a higher return or an even better risk-return ratio. Thus, we add to the literature unprecedented evidence for an emerging capital market, demonstrating that the creation of a listing segment alone does not guarantee the best performance but rather serves only as a showcase for such practices.

\section{Hypothesis development}

Corporate governance practices have different patterns across countries and it is necessary to identify endogenous factors in each country to assess the effects of legitimacy on the adoption of governance practices (Şahin, 2015). In this study, risk, return and risk compensation variables were evaluated as a means of identifying evidence on the legitimacy of firms by listing at the highest level of corporate governance in Brazil (Novo Mercado level). These measures are used to capture the chances of success or failure of the investment.

In theory, a firm with a higher level of governance tends to be identified as less risky (Rossoni \& Mendes-Da-Silva, 2018). This situation was identified in Brazil by Monte et al. (2010) when they observed lower risk and lower volatility in portfolios composed of firms of 
RAUSP

56,1

all different levels of governance when compared with the general market portfolio. Similarly, Silva et al. (2011) analyzed the relationship between the risk of a portfolio, considered sufficiently diversified and composed of firms of the Corporate Governance Index (IGC) of the Brazilian Stock Exchange and a market portfolio, showing a lower investment risk in the IGC portfolio, even in levels of return. However, these studies do not make comparisons between levels of governance; nor do they consider only the firms at the Novo Mercado level as a parameter of analysis, as in this study.

Concerning corporate governance quality, Lameira (2012) created an index composed of 20 binary questions about governance and analyzed its association with corporate risk. Their results converged to a negative relationship between risk and their governance index. These findings are like Rossoni and Mendes-Da-Silva (2018). However, the factors presented by Silveira and Barros (2008) and Espejo and Clemente (2016) can be weighted in this relationship, together with those evidenced in Monte et al. (2010) and Silva et al. (2011).

According to Silveira and Barros (2008), the listing at the highest governance levels in Brazil does not directly influence the corporate governance quality of the firms. Espejo and Clemente (2016) show that at times such as the crisis of 2008, listing at the different levels of governance did not contribute to the reduction of corporate risk and greater disclosure of risk policies did not affect the volatility of listed companies at the Novo Mercado level. However, firms with better corporate governance tend to have better risk disclosure (Salem, Ayadi, \& Hussainey, 2019) and being voluntarily listed at the Novo Mercado level works as a seal of legitimacy for the company in the market (Rossoni \& Machado-da-Silva, 2013).

For Rossoni and Mendes-Da-Silva (2018) at the Novo Mercado level, there is an expectation for better performance and lower risk. The market perceives the risk of firms at the Novo Mercado level can be based on the legitimate aspect of adopting governance practices (Şahin, 2015; Rossoni \& Mendes-Da-Silva, 2018), ignoring the possibility that the riskiest firms might seek this listing specifically because they are riskier. Nevertheless, the key argument is that legitimacy facilitates effective governance (Jonsson, 2020). Thus, based on Scott's (1995) legitimacy theory, the evidence of legitimation of Brazilian companies (Rossoni \& Machado-da-Silva, 2013; Rossoni \& Mendes-Da-Silva, 2018) and the fact that corporate governance quality is explained by endogenous factors and not necessarily by listing at the Novo Mercado level (Silveira \& Barros, 2008), we present the first hypothesis of this study:

H1. The listing of firms at the Novo Mercado level shows a positive relationship with the risk of the investment due to the aim of the firms for legitimation in the market.

Concerning return, corporate governance can be understanding as a way in which suppliers of finance to firms assure themselves of getting a return on their investment (Jonsson, 2020). In this sense, Core, Guay and Rusticus (2006) investigated whether there is a causal relationship between weak governance and low returns. Their main results did not support this relationship. When analyzing countries in the Eurozone, Bauer, Gunster and Otten (2004) found a closer relationship between corporate governance and firm value to excess returns. Fuenzalida et al. (2013) identified a positive abnormal return for investors in Peruvian companies on the day of the announcement of a firm's entry into the Good Corporate Governance Index (GCGI).

In Brazil, Vilhena and Camargos (2015) do not observe better performance for firms at the different levels of governance when returns are measured under the accounting aspect (ROE). However, the relationship between performance and listing at these levels is generally positive when the market value is observed. Just as the positive relationship between the listing at these levels and firm value is associated with the expected precepts of 
firms adhering to the governance practices, it might also reveal possible interest of the firms with a high concentration of control in the option for the Novo Mercado level to obtain larger returns to shareholders. For Silveira and Barros (2008), the concentration of a firm's control in Brazil negatively influences its corporate governance quality; therefore, compatible returns can be observed between firms regardless of whether they belong to the Novo Mercado level.

Given this context and under the assumption that the listing firms at the Novo Mercado level are a form of legitimation, we can expect a lower return on investment by firms at this level compared with those not listed at this level. According to Rossoni and Mendes-DaSilva (2018), legitimate companies tend to have access to resources and have better market valuation. From this perspective, firms with lower profitability have the motivation to submit to the listing costs at the different levels of $\mathrm{B}^{3}$ because they seek easier access to financial resources and greater market value.

Thus, even without high returns, the firms would already be legitimized by the listing at the special level of governance. Especially due to the market expectation for better performance to other companies (Rossoni \& Machado-da-Silva, 2013) and the perspective of stakeholders for management practices well accepted by the market (Sahin, 2015), which converges with the pressure environment that arises on companies that seek legitimation (Jonsson, 2020). Therefore, we present the second hypothesis:

H2. The listing of firms at the Novo Mercado level has a negative relationship with return on investment due to the finality of firms for legitimation in the market.

Another approach to analyzing the listing at the Novo Mercado level as part of the firm legitimation process is through the Sharpe (1964) Index, which proposes to present the excess return, relative to a risk-free asset, that a firm generated for each unit of risk (risk-return ratio). Milani et al. (2012) verified whether investments in firms with better corporate governance practices performed better than the other firms and found lower volatility among all indexes and a higher average return per unit risk (Sharpe Index) for firms with better governance. For Jonghe et al. (2012), there are conditionalities for the efficiency of risk-return through corporate governance, among which are regulation, the economy and the monitoring environment, all of which are compromised by the existence of inefficiencies in the Brazilian environment.

According to Dash and Raithatha (2019), corporate governance has a positive association with firms' performance. However, it fails to provide excess risk-adjusted returns to investors, especially because governance information is well assimilated in prevailing stock prices. The rationality of investors, seeking to minimize risk and maximize return, points to a positive relationship between the listing at the Novo Mercado level and excess riskadjusted return. In this study we seek to capture the legitimacy effect, so, our expectation is reversed. We expect a negative relationship between the risk compensation of investment and the listing, explained by the natural legitimacy of the firm in demonstrating its ability to pay its risk. We, therefore, have the third hypothesis of this study:

H3. The listing of firms at the Novo Mercado level has a negative relationship with the risk compensation of investment due to the goal of the firm for legitimation in the market.

\section{Methodology}

This study analysis 205 non-financial companies listed on the Brazilian Stock Exchange $\left(\mathrm{B}^{3}\right)$. The composition of the sample considered the availability of quarterly information in 
RAUSP

56,1

60

the period from 2010 to 2019. For this reason, observations of firms with missing data in each quarter and of firms with negative equity were excluded.

In the end, we analyzed 5,933 observations, with 103 companies at the Novo Mercado (2,919 observations) and the rest at the other segments. The classification of firms through levels observed the listing of firms at the end of each period, according to information available on the $\mathrm{B}^{3}$ website. Changes in levels between periods were captured because each company emerged on another level in the following period.

\subsection{Identification of risk, return and expected relationships}

Beta and Value at Risk (VaR) were used to analyze the investment risk. The Beta corresponds to the risk of each firm to the market, a systematic risk (Rossoni \& Mendes-DaSilva, 2018). The VaR represents the worst possible loss from the occurrence of extreme events (percentile $1 \%$ ) to the invested company, a non-systematic risk, one of the most widely used models in risk management (Olson \& Wu, 2017). Therefore, we capture as total investment risk the systematic and non-systematic (idiosyncratic) risks. For return on investment, we calculated the return of the stock (Vilhena \& Camargos, 2015) and Return on Equity (ROE) of the invested company (Fuenzalida et al., 2013) under the justification of indicating, respectively, the economic return (also sensitive to unmeasurable accounting factors) and financial return (sensitive only to measurable accounting factors).

Besides, the joint relationship between risk-return and listing at the Novo Mercado level is analyzed using the Sharpe Index, considering the investment risk compensation (Jonghe et al., 2012). Also, to control the effects size (total assets logarithm) and leverage (ratio into gross debt and total assets), characteristics that are intrinsic to the firms are added to the estimated models' two control variables.

\subsection{Estimated models}

The listing at the different levels of corporate governance gave rise to binary and categorical dependent variables. Therefore, we use logit regressions, binary and multinomial, to analyze the relationship of this listing with risk and return, according to equation (1). We also apply a multinomial model to analyze the marginal effects of the possible level of change between companies:

$$
P=\frac{1}{1+e^{-\left(\beta_{0}+\beta_{1} X_{1}+\beta_{2} X_{2}+\ldots+\beta_{k} X_{k}\right)}}
$$

The coefficients of logit models can be estimated by maximum likelihood. This estimator is consistent and usually distributed in large samples so that the $z$-statistics and the confidence intervals for the coefficients can be constructed in the usual way. Consequently, the model estimated in this study is based on equation (2):

$$
\begin{aligned}
\ln \left(\frac{\mathbf{p}_{\text {it }}}{1-\mathbf{p}_{\text {it }}}\right)= & \alpha_{0}+\beta_{1} B_{i t}+\beta_{2} V_{a} R_{i t}+\beta_{3} R_{i t}+\beta_{4} R O E_{i t}+\beta_{5} S I_{i t} \\
& +\beta_{6} \text { Size }_{i t}+\beta_{7} \text { Lev }_{i t}+\delta_{t}
\end{aligned}
$$

Where $P\left(N M_{i t}=1\right)$ is the probability that the firm will be listed at the Novo Mercado level, represented by the logarithm of the probability ratio of $p_{i t}$. For every firm $i$ in quarter $t: B_{i t}$ is the Beta; $V a R_{i t}$ is the Value at Risk; $R_{i t}$ is the stock return in the period; $R O E_{i t}$ is the Return 
on Equity; $S_{i t}$ is the Sharpe Index; Size $i t$ is the natural logarithm of market value on the last day of the period; $L e v_{i t}$ is the leverage ratio; $\delta_{t}$ represent time fixed-effects.

We use as a benchmark the best corporate governance standard, the Novo Mercado level (Monte et al., 2010; Dalmácio et al., 2013; Martins \& Paulo, 2014; Rossoni \& Mendes-DaSilva, 2018). Also, we use logit multinomial models, whose dependent variable is now represented by categories. In this study, we adopted the value 0 (zero) for firms that are at the Novo Mercado, value 1 (one) for firms in Level 1, value 2 (two) for firms in Level 2 and value 3 (three) for firms at the Traditional Segment. In both models, the Novo Mercado level was chosen as a reference variable for the estimates.

\section{Results}

The descriptive analysis of the data, presented in Table 1 , reveals that the average systematic risk of the investment, represented through the Beta, is higher among the firms listed at Level 1 (0.818), with the firms at the Novo Mercado level presenting the secondhighest average (0.795), whereas firms at the Traditional segment have the lowest average (0.594), although this segment, in theory, brings together companies that do not have additional commitments with corporate governance practices. In respect to $V a R$, the Traditional segment and the Novo Mercado level brought together firms with the highest average of non-systematic risk (8.090 and 6.505, respectively).

Concerning the stock return or economic return, the Novo Mercado and the Traditional segment also had the lowest average stock return (3.223 and 2.368, respectively), whereas the highest average was of firms in Levels 1 and 2 (3.439 and 3.441, respectively).

Concerning financial return, that on equity $(R O E)$, the highest average was observed among firms at the Traditional segment $(2.64 \%)$. The lowest mean $R O E$ was observed among firms of Level $2(2.80 \%)$, the segment with a lower number of firms and a high standard deviation of $R O E$. The proportion of firms with losses at this level was higher than for the others. The risk-return ratio, measured by the Sharpe Index, was higher for firms at the Traditional segment (0.114), indicating that the increase of $1.00 \%$ in risk refers to an increase of $1.11 \%$ points in the return. The firms with the worst risk compensation are those at Level 2 (0.036).

However, comparing the averages between levels with differentiated governance, we noticed that the Traditional segment has presented the highest risk compensation (0.114), indicating that firms at the segment that suggests the lowest governance standards have a better risk-return relationship. Firms at Level 1 have a higher average size (16.565), whereas the lowest average is from companies at the Traditional segment (13.663). Finally, the firms with the highest Leverage are at the Traditional segment (0.412) and level $2(0.418)$ and the least Leveraged are at the Novo Mercado level (0.357) and level 1 (0.276).

\begin{tabular}{|c|c|c|c|c|c|c|c|c|c|}
\hline \multirow[b]{2}{*}{ Variables } & \multicolumn{2}{|c|}{ Traditional } & \multicolumn{2}{|c|}{ Level 1} & \multicolumn{2}{|c|}{ Level 2} & \multicolumn{2}{|c|}{ Novo mercado } & \\
\hline & Mean & $\mathrm{SD}$ & Mean & SD & Mean & SD & Mean & $\mathrm{SD}$ & \\
\hline Beta & 0.594 & 0.299 & 0.818 & 0.334 & 0.776 & 0.306 & 0.795 & 0.302 & \\
\hline Value at risk & 8.090 & 4.864 & 6.043 & 2.189 & 5.871 & 2.017 & 6.505 & 3.253 & \\
\hline Return & 2.368 & 24.272 & 3.439 & 22.318 & 3.441 & 22.395 & 3.223 & 23.261 & \\
\hline$R O E$ & 0.026 & 0.194 & 0.021 & 0.094 & 0.003 & 0.205 & 0.013 & 0.166 & Table 1. \\
\hline Sharpe index & 0.114 & 0.484 & 0.047 & 0.433 & 0.036 & 0.515 & 0.037 & 0.482 & Descriptive statistics \\
\hline Size & 13.663 & 1.941 & 16.565 & 1.404 & 15.918 & 1.704 & 15.233 & 1.436 & of the variables \\
\hline Leverage & 0.412 & 0.643 & 0.276 & 0.157 & 0.418 & 0.185 & 0.357 & 0.269 & $(2010-2019)$ \\
\hline
\end{tabular}


RAUSP

56,1

\section{2}

Table 2.

Testing differences between means (2010-2019)
From these data, we analyze the significance of the differences between the means of each level of corporate governance and the means of the other firms, presented in Table 2. The firms of the Traditional and the Novo Mercado levels stand out to the others. We can verify that the Beta of the firms at the Traditional segment is on average -0.203 less than the Betas of the other sample firms.

The Novo Mercado firms presented an average of 0.137 higher. Conversely, the VaR of the Traditional segment was higher (1.710), whereas, at the Novo Mercado level, it was on average -0.942 lower. In terms of return, the economic return (stock return) was not statistically significant. On the other hand, the $R O E$ was 0.013 higher at the Traditional segment and -0.009 lower at the Novo Mercado level.

The Sharpe Index $(S I)$ was positive and significant at the Traditional segment (0.076), whereas the firms at the Novo Mercado had a lower average $(-0.056)$, which suggests that although the Beta is larger at the Novo Mercado, this higher risk is no being proportionally compensated. This is in line with Dash and Raithatha (2019). We also observed that Traditional firms tend to be smaller $(-1.839)$ and more leveraged than are the others $(0.063)$.

Table 3 shows the correlation matrix between the risk, return and control variables. Beta and $V a R$ were positively associated (0.352), as were stock return and $R O E(0.056)$. The Sharpe Index was negatively associated with the Beta $(-0.072)$ and positively associated with the return, either to the stock return $(0.217)$ or $R O E(0.124)$. The relationship between firm size and the risk was not clear, considering the positive association with Beta (0.132) and a negative association with $\operatorname{VaR}(-0.385)$.

However, its association with all return variables and Sharpe Index was positive and significant, except $R O E$. Leverage was positively and significantly associated with risk and was negative and significant with the return and Sharpe Index.

Based on these analyzes, it is possible to verify that among the four levels of corporate governance of the Brazilian stock exchange, two of them stand out, either by the number of firms or by the differences of averages observed: Traditional and Novo Mercado levels. This

\begin{tabular}{|c|c|c|c|c|}
\hline Variables & Traditional & Level 1 & Level 2 & Novo mercado \\
\hline Beta & -0.203 *** & $0.103 * * *$ & $0.053 * * *$ & 0.137 *** \\
\hline Value at risk & $1.710 * * *$ & -1.049 **** & -1.172 *** & $-0.942 * * *$ \\
\hline Return & -0.907 & 0.540 & 0.512 & 0.527 \\
\hline$R O E$ & $0.013 * *$ & 0.003 & -0.016 & $-0.009 * *$ \\
\hline Sharpe index & 0.076 *** & -0.019 & -0.031 & $-0.056 * * *$ \\
\hline Size & $-1.839 * * *$ & 1.911 *** & 1.123 *** & $0.748 * * *$ \\
\hline Leverage & $0.063 * * *$ & -0.106 *** & $0.049 * * *$ & $-0.028 * *$ \\
\hline
\end{tabular}

Note: *** represents significance at the $10 \%$ level, $* *$ at the $5 \%$ level, and *** at the $1 \%$ level

\begin{tabular}{|c|c|c|c|c|c|c|c|}
\hline & Variables & Beta & $\operatorname{VaR}$ & Return & $R O E$ & Sharpe & Size \\
\hline \multirow{7}{*}{$\begin{array}{l}\text { Table } 3 \text {. } \\
\text { Correlation matrix of } \\
\text { the analyzed } \\
\text { variables ( } 2010- \\
\text { 2019) }\end{array}$} & Value at risk & $0.352 * * *$ & & & & & \\
\hline & Return & 0.019 & 0.006 & & & & \\
\hline & $R O E$ & $-0.048 * * *$ & $-0.052 * * *$ & 0.056 **** & & & \\
\hline & Sharpe & $-0.072 * * *$ & -0.008 & $0.217 * * *$ & $0.124 * * *$ & & \\
\hline & Size & $0.132 * * *$ & -0.385 *** & $0.039 * * * *$ & 0.003 & 0.078 **** & \\
\hline & Leverage & $0.053 * * *$ & $0.235 * * *$ & $-0.022 *$ & -0.015 & -0.102 *** & -0.179 *** \\
\hline & \multicolumn{7}{|c|}{ Note: $* * *$ represents significance at the $10 \%$ level, $* *$ at the $5 \%$ level, and $* * *$ at the $1 \%$ level } \\
\hline
\end{tabular}


observation reinforces the assumption of Dalmácio et al. (2013), Martins and Paulo (2014) and Rossoni and Mendes-Da-Silva (2018) when considering the Novo Mercado an indicative parameter of the differentiated level of corporate governance in Brazil.

It also follows Monte et al. (2010) and Lameira (2012), who observes that the firms of the Novo Mercado have a level of risk different from the other corporate governance levels of the Brazilian stock exchange. Finally, we can observe that the variables representative of the firm's systematic and non-systematic risks, together with its economic and financial returns, show significant associations, which allows us to make inferences concerning listing at the Novo Mercado level as a legitimation tool to risk and return in Brazil.

Table 4 presents four logit regression models, with a dummy variable to be listed at the Novo Mercado level (value 1) and not at that level (value 0 ) as the dependent variable. With this analysis, we estimate the reason for a firm's listing at the Novo Mercado and for being riskier or more profitable to other firms. Additionally, we control the size, leverage and time in all estimated models.

Overall, the statistical tests indicate that the models are robust. For example, the McFadden $R^{2}$ show that the independent variables accounts for approximately $9,30 \%$ of the listing chance at the Novo Mercado level. The log-likelihood and Akaike I. C. point out that the models are well adjusted. The average VIF indicates no multicollinearity problems. Finally, Sensitivity, Specificity and Accuracy show the degree of accuracy of the models, greater than $60 \%$, approximately.

Model 1 relates the listing at the Novo Mercado level with risk variables, indicating significant associations. The listing is positive with Beta (2.020) but negative with VaR $(-0.126)$. Model 2 relates the listing at the Novo Mercado to return variables, indicating a significant and negative association only with $R O E(-0.273)$. The stock return in this period was not significant.

Model 3 relates this listing to risk compensation (Sharpe Index), indicating that the option for listing at the Novo Mercado has a negative and significant relationship with the Sharpe Index (-0.240), following Dash and Raithatha (2019). In all these models, size had a significant and positive relationship, indicating that firms listed at the Novo Mercado tend to be larger. While leverage no presented statistical relationship.

Model 4 allows us to analyze the associations of risk, return and risk compensation, simultaneously. In this model, we can verify that the associations initially observed are maintained, both in terms of significance and direction. In general, we note that the listing at the Novo Mercado level is positively associated with systematic risk (Beta) and negatively with non-systematic risk $(\mathrm{VaR})$ and the size effect also matters.

Being listed at the Novo Mercado implies an increase of $50.14 \%$ of the company's Beta, whereas its $V a R$ tends to be $-3.17 \%$ lower. This result suggests that the first hypothesis of this study $\left(H_{1}\right)$, that the listing at the Novo Mercado level is positively associated with risk, can be confirmed only for the systematic risk (Beta). This result is consistent with Espejo and Clemente (2016), who indicate that at times such as the crisis, listing at the different levels of governance did not contribute to the reduction of corporate risk. In this period, we had a local crisis in Brazil, with the impeachment of a President.

In model 3, we can observe that $H 2\left(H_{2}\right)$, that the listing at the Novo Mercado level has no association with financial return $(R O E)$ and stock return, which rejects the research hypothesis. This evidence agrees with Vilhena and Camargos (2015), who did not observe better performance for firms at the different levels of governance in Brazil when returns were measured under the accounting aspect $(R O E)$.

Alone (in model 3), the Shape Index has a negative association with the Novo Mercado linting, in line with Dash and Raithatha (2019). However, in the complete model (4), we 
RAUSP

56,1

64

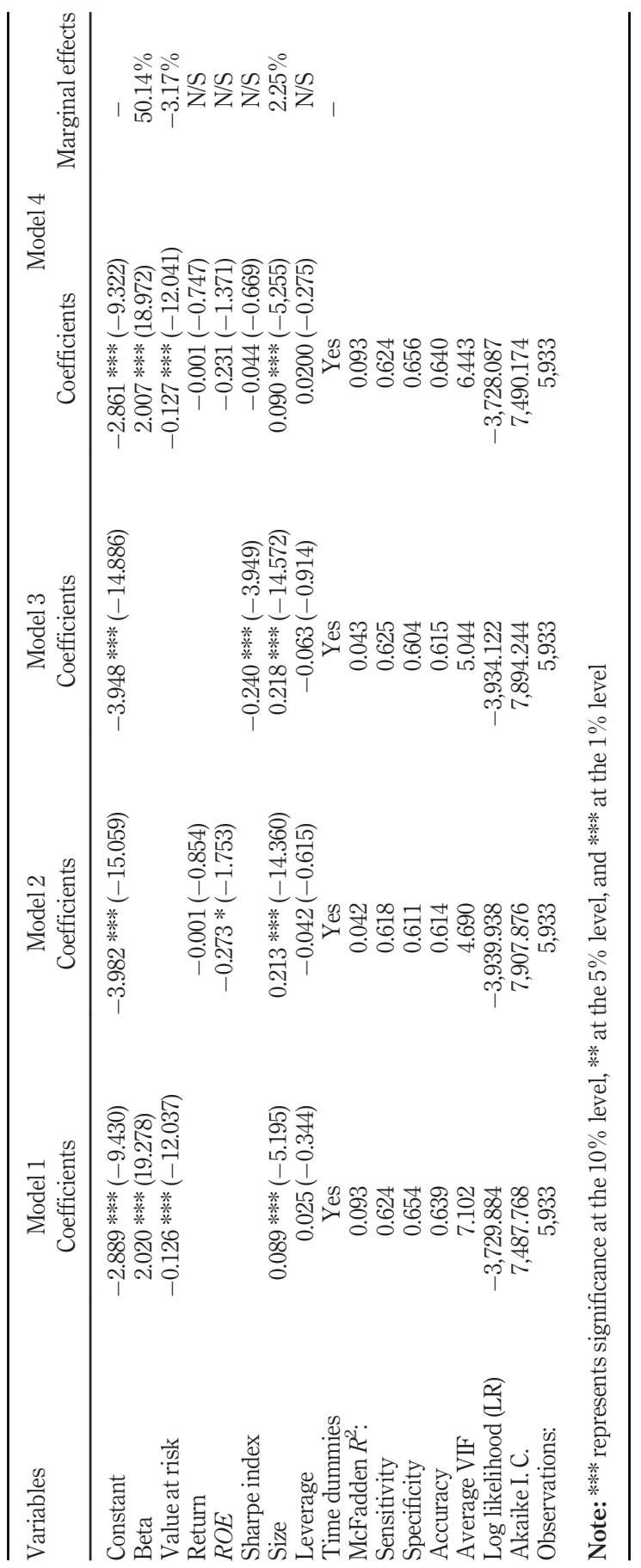

Table 4.

Relationship between listing at the novo mercado level, risk and return (20102019) 
cannot make inferences about the variation of risk compensation (Sharpe Index). So, the negative association between the listing at the Novo Mercado and risk compensation exists just when we do not control other risk and return factors.

Thus, we found evidence to confirm the third hypothesis of this study $\left(H_{3}\right)$ under this special condition. Our evidence is different from Milani et al. (2012) and following Hou, Xue and Zhang (2015) and Dash and Raithatha (2019), with the assumption of failures in the adjustment of return of assets to their risk factors. This situation is possible in Brazil because Brazilian companies exist in a specific environment that is characterized by a booming stock market. Conversely, size again showed a significant and positive association (0.090), indicating that being listed at the Novo Mercado has a positive marginal effect of $2.25 \%$ on the size of firms.

Based on the assumptions of Rossoni and Machado-da-Silva (2013) that Brazilian firms seek legitimacy at the Novo Mercado because they present a higher risk and of Silveira and Barros (2008) that the listing at the Novo Mercado does not necessarily reflect better quality of corporate governance, we find that our results are consistent with these authors. We observed that, after controlling for size, leverage and time effects, being at the Novo Mercado level meant that the company had a higher systematic risk.

Therefore, it is reasonable to consider that in Brazil, companies have been seeking to be listed at the Novo Mercado level by issuing a signal to the market in search of legitimacy, as observed in the related literature (Stanfield \& Carroll, 2004; Judge, Douglas, \& Kutan, 2008; Liu \& Taylor, 2008; Şahin, 2015; Rossoni \& Mendes-Da-Silva, 2018).

To test the robustness of our analysis, we evaluate each hypothesis considering the breakdown of all levels of corporate governance, making an individual comparison with listing at the Novo Mercado level, our benchmark. With this procedure, the effects of the listing at Levels 1 and 2 of corporate governance and at the Traditional segment were segregated because the governance requirements are not uniform between them and might influence the estimates presented in Table 4. This analysis was performed using multinomial logit regression, having as a benchmark the firms listed at the Novo Mercado and considering the marginal effects of the risk and the return of a company not listed at the Novo Mercado by opting for the listing at this level.

The results presented in Table 5 show the coefficients of each group compared with the group of firms at the Novo Mercado level. In this analysis, we seek to foster important discussions about the legitimacy aspect, particularly when we address listed companies at the level that supposedly has the best corporate governance standard of the Brazilian stock exchange (Novo Mercado) and particularly when comparing these firms with those at the Traditional segment, which have no formal commitment to $\mathrm{B}^{3}$ concerning corporate governance practices.

In Table 5, we can verify the coefficients and marginal effects of the change at the level of corporate governance of companies, leaving the reference group (Novo Mercado) for each of the other levels of corporate governance of the stock exchange. In particular, the comparisons of the two main listing segments of the Brazilian stock exchange (Traditional and Novo Mercado) ratify our findings.

With the remaining conditions constant, we noticed that the change from the listing segment of the Novo Mercado level to the Traditional segment negatively affects the systematic risk and positively affects the financial return and the risk compensation of the firms. That is, the option to remain at the Traditional segment represents a Beta $-48.60 \%$ lower than the firms at the Novo Mercado and a 2.31\% higher VaR, a 6.27\% higher Sharpe Index and $\mathrm{a}-8.6 \%$ lower size. 
RAUSP

56,1

66

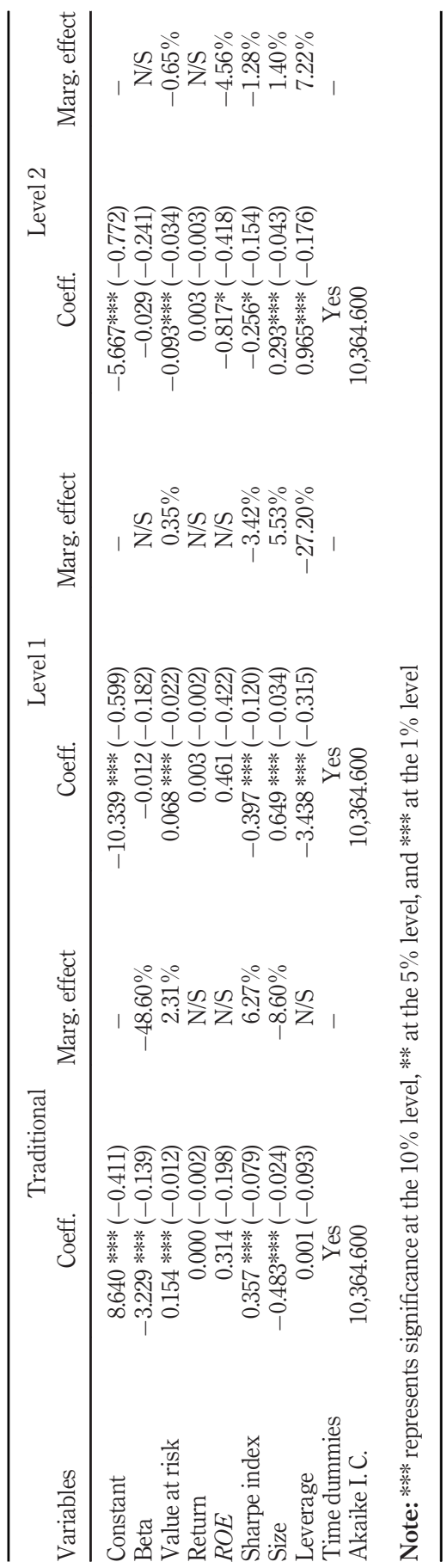

Table 5.

Multinomial logit model for listing at the novo mercado level of corporate governance (20102019) 
Again, these findings confirm the hypothesis that the listing at the Novo Mercado level is associated with higher systematic risk (consistent with $H_{1}$ ), according to Silveira and Barros (2008), Rossoni and Machado-da-Silva (2013), Vilhena and Camargos (2015) and Espejo and Clemente (2016). Also, and from an exclusive range for the group of firms at the Traditional segment, we observed that the exit of the Novo Mercado level represents an increase in the Sharpe Index, which is consistent with $H 3$ of this study $\left(H_{3}\right)$, that is, that firms listed at the Novo Mercado have lower risk compensation, and therefore seek to legitimize themselves at the Novo Mercado.

These findings are different from Milani et al. (2012) but can be explained by the constraints of the Brazilian market such as the regulation, the economic crisis and the monitoring environment (Jonghe et al., 2012), which lead them to seek to differentiate in the market through legitimation at the Novo Mercado.

Concerning the intermediate levels of corporate governance, Level 1 and Level 2, we observe that the change from the Novo Mercado to Level 1 is associated with the marginal effects of $V a R$ increase $(0.35 \%)$, risk compensation reduction $(-3.42 \%)$, size increase $(5.53 \%)$ and leverage decrease $(-27.20 \%)$. The change from the Novo Mercado to Level 2 is the one that has the smallest marginal effects, is only associated with the $\operatorname{VaR}$ decrease $(-0.65 \%)$, the $R O E$ decrease $(-4.56 \%)$ and the Sharpe Index decrease $(-1.28 \%)$ and an increase in the size $(1.40 \%)$ and the leverage $(7.22 \%)$. In all these cases, the results are conditional on the maintenance of the other constant variables.

\section{Conclusion}

Our findings show that a listing at the Novo Mercado level, the supposedly higher level of corporate governance in Brazil, does not indicate lower risk, a higher return or even a better risk-return ratio. Going beyond common sense and past evidence, our analysis of the phenomenon of the firm being listed in a special segment of corporate governance works as a legitimation of the company before the market. This listing is like a kind of "seal" that the riskiest companies look for when they want greater credibility with the market.

This conclusion is especially important when we look at systematic risk, being the most common in the analysis of investments, especially in asset pricing models, as in CAPM. Also, considering the risk-adjusted return, we conclude that there is not enough compensation for the higher risk level of the companies listed at the Novo Mercado.

In this sense, the contributions of this study go beyond demonstrating that listing at the Novo Mercado is not a guarantee of lower risk and a greater return. The evidence that the Novo Mercado brings together companies with greater systematic risk and less risk compensation contributes to the reflection on the purpose and effectiveness of the existence of a special level of corporate governance on the Brazilian stock exchange.

Should Novo Mercado bring together companies that "appear" to have less risk and a better risk-return ratio or are these characteristics important for investors to have greater security in allocating their resources? The listing in this special segment represents a cost for companies and their shareholders, as a complex governance structure is necessary for the required practices to be followed. However, managers, shareholders, regulatory agents and the stock exchange itself must reflect on the effectiveness of these special segments and analyze whether the benefits of this listing outweigh the costs.

Finally, we highlight the relevance of the listing at the Novo Mercado level in the process of legitimizing companies. If investors are looking for the best companies to invest in the Brazilian capital market, the decision based on the option for the Novo Mercado level is not enough to identify them. Of course, our findings are limited to the sample analyzed and the 
RAUSP

56,1

types of risks and returns we studied. We have not eliminated the possibility of other factors justifying listing at the Novo Mercado and for this reason, our results should be part of understanding a broader context.

\subsection{Limitations and implications}

The listed companies at the Novo Mercado induce investors to associate them to lower risk because of the adoption of corporate governance best practices. However, some companies such as Petrobrás, Itaú Unibanco, Bradesco, Gerdau and others, are not listed at the Novo Mercado, but at the New York Stock Exchange (NYSE), which requires an even higher standard of corporate governance from companies. In this sense, the Novo Mercado level may not include all companies which adopt effective corporate governance practices. This is confirmed by our study, which found that companies at the Novo Mercado have more chances to be riskier.

This context is closely aligned with IBGC (2018) survey which showed that companies at the Novo Mercado do not adopt more corporate governance practices than other companies. In this sense, recently different players discussed changes in the Novo Mercado regulation, which was approved in 2017, with a deadline for total implementation by 2021. Despite this, some stakeholders have warned that the changes are not enough.

Another recent technical report from KPMG (2019) made an analysis of companies in Brazil and showed that firms at the Novo Mercado level do not yet have better corporate governance structures than other companies. This evidence is in contrast to the theoretical risk-return relationship, finding support in the legitimacy theory. Then, this has an important social implication for the market, as it represents nonsense.

This is the main contribution of this study to the discussions about the corporate governance practices required in the Brazilian market. Despite the recent changes in the Novo Mercado regulation, we can see that we still have a long way to go. The listing in this supposed upper segment of corporate governance does not work effectively. Then, as the listing at this segment represents a cost to the company, just as discussions of new rules represent a cost to society, the benefits must be effective and not just a form of legitimation.

Future studies can look at the phenomenon along the lines of organizational isomorphism to complement the findings related to legitimation. Especially in the most recent Brazilian context, marked by a rising stock market, with many firms seeking to follow this trend with the realization of Initial Public Offers (IPO), presenting the listing at the Novo Mercado level as a form of homogenization, reducing the chances for the market to differentiate these companies due to the quality of their corporate governance.

\section{References}

Bauer, R., Gunster, N., \& Otten, R. (2004). Empirical evidence on corporate governance in Europe - the effect on stock returns, firm value, and performance. Journal of Asset Management, 5(2), 91-104. doi: https://doi.org/10.1057/palgrave.jam.2240131.

Core, J., Guay, W., \& Rusticus, T. (2006). Does weak governance cause weak stock returns? an examination of firm operating performance and investors' expectations. The Journal of Finance, 61(2), 655-687. doi: https://doi.org/10.1111/j.1540-6261.2006.00851.x.

Dalmácio, F. Z., Lopes, A. B., Rezende, A. J., \& Sarlo Neto, A. (2013). An analysis of the relationship between corporate governance and accuracy of the analyst's forecasts of the Brazilian market. Ram. Revista de Administração Mackenzie, 14(5), 104-139. doi: https://doi.org/10.1590/S167869712013000500005. 
Dash, S. R., \& Raithatha, M. (2019). Corporate governance and firm performance relationship: Implications for risk-adjusted return behavior. Managerial and Decision Economics, 40(8), 923940. doi: https://doi.org/10.1002/mde.3080.

Espejo, R. A., \& Clemente, A. (2016). Os níveis de governança corporativa enquanto fatores redutores de risco na crise financeira de 2008. Revista de Contabilidade Do Mestrado em Ciências Contábeis da UERJ, 21(2), 34-51.

Fernandes, N. A. C., Dias, W. O., \& Cunha, J. V. A. (2010). Governança corporativa no contexto brasileiro: Um estudo do desempenho das companhias listadas nos níveis da BM\&FBovepa. Revista Organizações em Contexto, 6(11), 22-44. doi: https://doi.org/10.15603/1982-8756/roc. v6n11p22-44.

Fuenzalida, D., Mongrut, S., Arteaga, J. R., \& Erausquin, A. (2013). Good corporate governance: Does it pay in Peru? Journal of Business Research, 66(10), 1759-1770. doi: https://doi.org/10.1016/j. jbusres.2013.01.008.

Hou, K., Xue, C., \& Zhang, L. (2015). Digesting anomalies: an investment approach. Review of Financial Studies, 28(3), 650-705. doi: https://doi.org/10.1093/rfs/hhu068.

IBGC. (2018). Pratique ou explique: análise quantitativa dos informes das companhias abertas brasileiras, São Paulo: IBGC.

Jonghe, O., Disli, M., \& Schoors, K. (2012). Corporate governance, opaque bank activities and risk/return efficiency: Pre-and post-crisis evidence from Turkey. Journal of Financial Services Research, 41(1-2), 51-80. doi: https://doi.org/10.1007/s10693-011-0115-x.

Jonsson, E. I. (2020). Corporate governance and corporate legitimacy: The role of boards. In J. Rendtorff, (Ed.) Handbook of business legitimacy, Cham: Springer.

Judge, W. Q., Douglas, T. J., \& Kutan, A. M. (2008). Institutional antecedents of corporate governance legitimacy. Journal of Management, 34(4), 765-785. doi: https://doi.org/10.1177/0149206 308318615.

KPMG. (2019). A governança corporativa e o mercado de capitais, 14a ed., São Paulo: KPMG.

Lameira, V. J. (2012). The relationships between governance and risk in Brazilian companies. Review of Business Management, 14(42), 7-25. doi: https://doi.org/10.7819/rbgn.v14i42.871.

Liu, J., \& Taylor, D. (2008). Legitimacy and corporate governance determinants of executives' remuneration disclosures. Corporate Governance: The International Journal of Business in Society, 8(1), 59-72. doi: https://doi.org/10.1108/14720700810853400.

Martins, O. S., \& Paulo, E. (2014). Information asymmetry in stock trading, economic and financial characteristics, and corporate governance in the Brazilian stock market. Accounting \& Finance Review, 25(64), 33-45.

Milani, B., Righi, M. B., Ceretta, P. S., \& Dias, V. V. (2012). Práticas de sustentabilidade, governança corporativa e responsabilidade social afetam o risco e o retorno dos investimentos? Revista de Administração da Ufsm, 5, 667-682. doi: https://doi.org/10.5902/198346596946.

Monte, P. A., Rezende, I. C. C., Teixeira, G. S., \& Besarria, C. N. (2010). Is there a relationship between corporate governance and volatility? A study from the composed portfolios. Revista Contabilidade Vista \& Revista, 21(2), 15-44.

Olson, D. L., \& Wu, D. D. (2017). Value at risk models. Enterprise risk management models, Berlin, Heidelberg: Springer Texts in Business and Economics, Springer.

Rossoni, L., \& Machado-da-Silva, C. L. (2013). Legitimacy, corporate governance, and performance in BM\&FBovespa. RAE, 53(3), 272-289.

Rossoni, L., \& Mendes-Da-Silva, W. (2018). How does legitimacy operate in emerging capital markets? Investigating the moderating effects of premium listings and firm size on risk. Canadian Journal of Administrative Sciences/Revue Canadienne Des Sciences de L'administration, 36(3), 404-417. doi: https://doi.org/10.1002/cjas.1496. 
RAUSP

56,1

Şahin, K. (2015). The legitimacy of codes of corporate governance: Perspectives from developed and emerging economies. Journal of Management \& Governance, 19(3), 687-708. doi: https://doi.org/ 10.1007/s10997-014-9289-6.

Salem, I. H., Ayadi, S. D., \& Hussainey, K. (2019). Corporate governance and risk disclosure quality: Tunisian evidence. Journal of Accounting in Emerging Economies, 9(4), 567-602. doi: https://doi. org/10.1108/JAEE-01-2019-0005.

Scott, W. R. (1995). Organizations and institutions. Foundations for organizational science, Thousand Oaks, CA: Sage Publications.

Sharpe, W. F. (1964). Capital asset prices: A theory of market equilibrium under conditions of risk. The Journal of Finance, 19(3), 425-442.

Silva, R. L. M., Nardi, P. C. C., \& Pimenta Júnior, T. (2012). O impacto da migração das empresas para os níveis diferenciados de governança corporativa da BM\&FBovespa sobre o risco e o retorno de suas ações. Revista de Administração da UFSM, 5(2), 222-242.

Silveira, A. D. M. S., \& Barros, L. A. B. C. (2008). Determinants of corporate governance quality of Brazilian listed companies. Revista Eletrônica de Administração, 14(3), 512-540.

Stanfield, J. R., \& Carroll, M. C. (2004). Governance and the legitimacy of corporate power: A path for convergence of heterodox economics? Journal of Economic Issues, 38(2), 363-370. doi: https://doi. org/10.1080/00213624.2004.11506695.

Vilhena, F. A. C., \& Camargos, M. A. (2015). Corporate governance, value creation and economic and financial performance: Evidences of Brazilian market with panel data, 2005-2011. Revista de Gestão, 22(1), 77-96. doi: https://doi.org/10.5700/rege552.

Woodward, D. G., Edwards, P., \& Birkin, F. (1996). Organization legitimacy and stakeholder information provision. British Journal of Management, 7(4), 329-347. doi: https://doi.org/ 10.1111/j.1467-8551.1996.tb00123.x.

\section{Corresponding author}

Orleans Silva Martins can be contacted at: orleansmartins@yahoo.com.br

Associate Editor: Tobias Coutinho Parente

For instructions on how to order reprints of this article, please visit our website:

www.emeraldgrouppublishing.com/licensing/reprints.htm

Or contact us for further details: permissions@emeraldinsight.com 